Article

\title{
Effect of Copper Precursors on the Activity and Hydrothermal Stability of $\mathrm{Cu}^{\mathrm{II}}-\mathrm{SSZ}-13$ $\mathrm{NH}_{3}-\mathrm{SCR}$ Catalysts
}

\author{
Meixin Wang ${ }^{1}$, Zhaoliang Peng ${ }^{1}$, Changming Zhang ${ }^{1}$, Mengmeng Liu ${ }^{1}$, Lina Han ${ }^{2}$, \\ Yaqin Hou ${ }^{3}$, Zhanggen Huang ${ }^{3}$, Jiancheng Wang ${ }^{1, *}$, Weiren Bao ${ }^{1}$ and Liping Chang ${ }^{1}$ \\ 1 Key Laboratory of Coal Science and Technology, Ministry of Education and Shanxi Province, Taiyuan \\ University of Technology, Taiyuan 030024, China; wangmeixinabc@yeah.net (M.W.); \\ pengzhaoliang@tyut.edu.cn (Z.P.); zhangchangming@tyut.edu.cn (C.Z.); liumengmeng@tyut.edu.cn (M.L.); \\ baoweiren@tyut.edu.cn (W.B.); lpchang@tyut.edu.cn (L.C.) \\ 2 College of Materials Science and Engineering, Taiyuan University of Technology, Taiyuan 030024, China; \\ hanlina@tyut.edu.cn \\ 3 State Key Laboratory of Coal Conversion, Institute of Coal Chemistry, Chinese Academy of Sciences, \\ Taiyuan 030001, China; houyaqin@sxicc.ac.cn (Y.H.); zghuang@sxicc.ac.cn (Z.H.) \\ * Correspondence: wangjiancheng@tyut.edu.cn; Tel.: +86-138-3462-9730
}

Received: 29 August 2019; Accepted: 17 September 2019; Published: 19 September 2019

\begin{abstract}
A series of $\mathrm{Cu}^{\mathrm{II}}-\mathrm{SSZ}-13$ catalysts are prepared by in-situ hydrothermal method using different copper precursors $\left(\mathrm{Cu}^{\mathrm{II}}\left(\mathrm{NO}_{3}\right)_{2}, \mathrm{Cu}^{\mathrm{II}} \mathrm{SO}_{4}, \mathrm{Cu}^{\mathrm{II}} \mathrm{Cl}_{2}\right)$ for selective catalytic reduction of $\mathrm{NO}$ by $\mathrm{NH}_{3}$ in a simulated diesel vehicle exhaust. The catalysts were characterized by $\mathrm{X}$-ray diffraction (XRD), scanning electron microscope (SEM), X-ray photoelectron spectroscopy (XPS), $\mathrm{N}_{2}$ adsorption-desorption, hydrogen-temperature-programmed reduction $\left(\mathrm{H}_{2}-\mathrm{TPR}\right)$, ammonia temperature-programmed desorption ( $\left.\mathrm{NH}_{3}-\mathrm{TPD}\right)$, and ${ }^{27} \mathrm{Al}$ and ${ }^{29} \mathrm{Si}$ solid state Nuclear Magnetic Resonance (NMR). The $\mathrm{Cu}{ }^{\mathrm{II}}-\mathrm{SSZ}-13$ catalyst prepared by $\mathrm{Cu} \mathrm{u}^{\mathrm{II}}\left(\mathrm{NO}_{3}\right)_{2}$ shows excellent catalytic activity and hydrothermal stability. The NO conversion of $\mathrm{Cu}^{\mathrm{II}}-\mathrm{SSZ}-13$ catalyst prepared by $\mathrm{Cu}^{\mathrm{II}}\left(\mathrm{NO}_{3}\right)_{2}$ reaches $90 \%$ at $180{ }^{\circ} \mathrm{C}$ and can remain above $90 \%$ at a wide temperature range of $180-700^{\circ} \mathrm{C}$. After aging treatment at $800^{\circ} \mathrm{C}$ for $20 \mathrm{~h}$, the $\mathrm{Cu}{ }^{\mathrm{II}}-\mathrm{SSZ}-13$ catalyst prepared by $\mathrm{Cu}^{\mathrm{II}}\left(\mathrm{NO}_{3}\right)_{2}$ still exhibits above $90 \% \mathrm{NO}$ conversion under a temperature range of $240-600{ }^{\circ} \mathrm{C}$. The distribution of $\mathrm{Cu}$ species and the $\mathrm{Si} / \mathrm{Al}$ ratios in the framework of the synthesized $\mathrm{Cu}^{\mathrm{II}}-\mathrm{SSZ}-13$ catalysts, which determine the catalytic activity and the hydrothermal stability of the catalysts, are dependent on the adsorption capacity of anions to the cation during the crystallization process due to the so called Hofmeister anion effects, the $\mathrm{NO}_{3}{ }^{-}$ion has the strongest adsorption capacity among the three kinds of anions $\left(\mathrm{NO}_{3}{ }^{-}, \mathrm{Cl}^{-}\right.$, and $\left.\mathrm{SO}_{4}{ }^{2-}\right)$, followed by $\mathrm{Cl}^{-}$and $\mathrm{SO}_{4}{ }^{2-}$ ions. Therefore, the $\mathrm{Cu}{ }^{\mathrm{II}}-\mathrm{SSZ}-13$ catalyst prepared by $\mathrm{Cu}^{\mathrm{II}}\left(\mathrm{NO}_{3}\right)_{2}$ possess the best catalytic ability and hydrothermal stability.
\end{abstract}

Keywords: selective catalytic reduction; $\mathrm{Cu}^{\mathrm{II}}-\mathrm{SSZ}-13$; copper precursor; hydrothermal stability; emission control of diesel engine exhaust

\section{Introduction}

The emission of nitrogen oxides is a major cause of unhealthy air quality and is strictly regulated in many places. To meet regulations, controlling the emission of nitrogen oxides from diesel exhaust is one important topic in catalysis [1,2]. The selective catalytic reduction of $\mathrm{NO}_{\mathrm{x}}$ by ammonia $\left(\mathrm{NH}_{3}-\mathrm{SCR}\right)$ is one of the most effective approaches to convert $\mathrm{NO}_{\mathrm{x}}$ due to its high fuel economy, and high denitrification efficiency [3,4]. The core issue of this technology is the development of environmentally friendly SCR catalysts with high activity, wide operating temperature window, and excellent hydrothermal stability. 
Prior to the application of molecular sieve catalysts, $\mathrm{NO}_{\mathrm{x}}$ abatement technology relied primarily on $\mathrm{V}_{2} \mathrm{O}_{5}-\mathrm{WO}_{3} / \mathrm{TiO}_{2}$ as a $\mathrm{NO}_{x}$ removal catalyst $[5,6]$. In recent years, the $\mathrm{Cu} \mathrm{u}^{\mathrm{II}}-\mathrm{SSZ}-13$ molecular sieve used as $\mathrm{NH}_{3}$-SCR catalysts has become a hot topic due to its wide temperature window, high $\mathrm{N}_{2}$ selectivity, and excellent hydrothermal stability [7-9]. In addition, $\mathrm{Cu}^{\mathrm{II}}-\mathrm{SSZ}-13$ shows its superiority in hydrothermal stability under moderate aging temperatures (e.g., $750-800{ }^{\circ} \mathrm{C}$ ) compared to other well-known Cu molecular sieves (e.g., Cu-ZSM-5, Cu-beta, and Cu-Y) [10].

Recently, the $\mathrm{Cu}^{\mathrm{II}}-\mathrm{SSZ}-13$ catalysts are usually synthesized by hydrothermal method and subsequent ion exchange process. Han et al. [11] prepared $\mathrm{Cu}^{\mathrm{II}}-\mathrm{SSZ}-13$ catalyst using $\mathrm{N}, \mathrm{N}$, $\mathrm{N}$-trimethyl-1-adamantane ammonium hydroxide (TMAda-OH) as template by microwave, dynamic and static hydrothermal methods, respectively. Shishkiny et al. [12] synthesized functionalized $\mathrm{Cu}^{\mathrm{II}}-\mathrm{SSZ}-13$ catalyst by introducing $\mathrm{Cu}$ and $\mathrm{Fe}$ ions into the Na-SSZ-13 catalyst during the ion exchange process. The industrial application of SSZ-13 molecular sieve catalyst is limited due to the high costs of TMAda-OH template. Ren et al. [13] developed an in situ method to synthesize $\mathrm{Cu}^{\mathrm{II}}$-SSZ-13 using low-cost copper teraethylenepentamine (Cu-TEPA) as template, which reduced economic cost the $\mathrm{Cu}^{\mathrm{II}}-\mathrm{SSZ}-13$ catalyst. Zhang et al. [14] compared $\mathrm{Cu}^{\mathrm{II}}-\mathrm{SSZ}-13$ catalysts prepared by ion-exchange ( $\left.\mathrm{Cu}^{\mathrm{II}}-\mathrm{SSZ}-13-\mathrm{I}\right)$ and in-situ synthesis methods ( $\left.\mathrm{Cu}^{\mathrm{II}}-\mathrm{SSZ}-13-\mathrm{O}\right)$, and found that $\mathrm{Cu}^{\mathrm{II}}-\mathrm{SSZ}-13-\mathrm{O}$ showed higher $\mathrm{DeNO}_{\mathrm{x}}$ activity and stronger Lewis acid site strengths than $\mathrm{Cu}^{\mathrm{II}}-\mathrm{SSZ}-13-\mathrm{I}$. Cu ${ }^{\mathrm{II}}-\mathrm{SSZ}-13$ was prepared by selecting a novel low-temperature solid-state ion-exchange (LT-SSIE) method using $\mathrm{Cu}^{\mathrm{II}} \mathrm{Ac}_{2}$ and $\mathrm{Cu}^{\mathrm{II}}\left(\mathrm{NO}_{3}\right)_{2}$ as $\mathrm{Cu}$ precursors, showing comparable SCR activity and hydrothermal stability to the traditional solution ion-exchanged $\mathrm{Cu}^{\mathrm{II}}-\mathrm{SSZ}-13$ with a similar $\mathrm{Cu}$ loading [15]. Paolucci et al. [16] have worked out a scenario that is based on the formation of the $\mathrm{Cu}$-ammonia complex $\mathrm{Cu}\left(\mathrm{NH}_{3}\right)_{2}{ }^{+}$mechanism shows that the actual active sites for $\mathrm{NO}_{\mathrm{x}}$ reduction are not static structures but dynamic and come and go as the reaction proceeds. Borfecchia et al. [17] provide a comprehensive overview on the structural complexity of $\mathrm{Cu}-\mathrm{CHA}$ materials, it has been shown that the active site in the low temperature $\mathrm{NH}_{3}-\mathrm{SCR}$ catalyst is a mobile $\mathrm{Cu}$-molecular entity that "lives in symbiosis" with an inorganic solid framework. Only in the high temperature $\mathrm{NH}_{3}-\mathrm{SCR}$ regime do the mobile $\mathrm{Cu}$ species lose their ligands and find docking sites at the internal walls of the molecular sieve framework. Marberger et al. [18] monitored the evolution of various $\mathrm{Cu}$ species in $\mathrm{Cu}^{\mathrm{II}}-\mathrm{SSZ}-13$ and experimentally identified crucial characteristics of the SCR catalyst in the low-temperature regime: the rate-limiting re-oxidation of $\mathrm{Cu}^{\mathrm{I}}\left(\mathrm{NH}_{3}\right)_{2}$ is strongly influenced by $\mathrm{NH}_{3}$ inhibition; the active $\mathrm{Cu}\left(\mathrm{NH}_{3}\right)_{4}$ species are mainly formed below $250{ }^{\circ} \mathrm{C}$; and the modification of the active sites with increasing temperatures is driven by the loss of $\mathrm{NH}_{3}$ coordinating $\mathrm{Cu}$ species.

It should be noted that the synthesis of molecular sieves via hydrothermal method is a multi-variable process. The crystallization temperature, duration, dynamic/static, as well as the prescriptions of anions and cations have important influences on the physicochemical properties of the final molecular sieve products, which further determine the performances of the catalysts. In the process of in-situ synthesis of $\mathrm{Cu}^{\mathrm{II}}-\mathrm{SSZ}-13$ catalyst, the distribution of metal cations on the molecular sieve framework determines its structure properties and catalytic performance. The metal cations can affect the aggregation state, condensation rate, and colloidal state of silicate materials in the formation in the reaction system [19]. The anions also have influences on the synthesis of silicon-alumina molecular sieves. It has been reported that the crystallization time of ZSM-5 and TS-1 can be regulated by the oxyacid anion [20]. In the early days, Hofmeister studied the ability of different salt solutions to denature proteins, and called the relative effectiveness of anions to produce different specificities on a wide range of phenomena the Hofmeister anion effect [21]. Alexander $\mathrm{V}$ [22] investigated a series of Hofmeister anions that may be arranged in the following sequence: $\mathrm{SO}_{4}{ }^{2-}>\mathrm{Cl}^{-} \sim \mathrm{NO}_{3}{ }^{-}$with decreasing zeolite Beta formation potency from left to right. The Hofmeister anion effect can influence the surface activity of the mesoporous materials. The adsorption ability of anion to the cation: $\mathrm{NO}_{3}{ }^{-}>\mathrm{Cl}^{-}>\mathrm{SO}_{4}{ }^{2-}[23,24]$. Anion species will change hydrolysis rate of silicate liquid precursor and the size of template agent micelle, which finally results in the differences of the surface properties and the morphology of molecular sieve catalyst after calcination. In short, the anion 
can change hydrolysis rate of precursor and the structure of colloid formed by the template agent, which affects the framework structure, crystal structure, morphology, and the catalytic properties of the final $\mathrm{Cu}^{\mathrm{II}}-\mathrm{SSZ}-13$ molecular sieve.

In this work, $\mathrm{Cu}^{\mathrm{II}}-\mathrm{SSZ}-13$ catalysts were prepared by in-situ hydrothermal synthesis method for $\mathrm{NO}$ selective catalytic reduction with $\mathrm{NH}_{3}$ in simulated diesel vehicles exhaust. Three kinds of copper precursors $\left(\mathrm{Cu}^{\mathrm{II}}\left(\mathrm{NO}_{3}\right)_{2}, \mathrm{Cu}^{\mathrm{II}} \mathrm{SO}_{4}, \mathrm{Cu}^{\mathrm{II}} \mathrm{Cl}_{2}\right)$ were used to investigate the effect of anions on the structure, catalytic activity, and hydrothermal stability of $\mathrm{Cu}^{\mathrm{II}}-\mathrm{SSZ}-13$ catalysts. The NO conversion, $\mathrm{N}_{2}$ selectivity, and the structure characterization of the fresh and aged $\mathrm{Cu}^{\mathrm{II}}-\mathrm{SSZ}-13$ catalysts were investigated in detail.

\section{Results and Discussion}

\subsection{Catalytic Activity}

Figure 1 shows the conversion of $\mathrm{NO}, \mathrm{N}_{2}$ selectivity, and $\mathrm{N}_{2} \mathrm{O}$ yield of fresh and aged $\mathrm{Cu}^{\mathrm{II}}-\mathrm{SSZ}-13$ catalysts. As shown in Figure 1a, the $\mathrm{Cu}^{\mathrm{II}}-\mathrm{SSZ}-13$ catalysts prepared by three kinds of copper precursors all exhibit excellent catalytic activity. Compared with the other samples, the NO conversion of the $\mathrm{F}-\mathrm{NO}_{3}$ sample reaches $90 \%$ at $180{ }^{\circ} \mathrm{C}$ and has a widest temperature window $\left(180-700{ }^{\circ} \mathrm{C}\right)$. The $\mathrm{Cu}^{\mathrm{II}}-\mathrm{SSZ}-13$ catalysts prepared by three kinds of copper precursors declines dramatically after aging at $800{ }^{\circ} \mathrm{C}$ for $20 \mathrm{~h}$ as shown in Figure $1 \mathrm{~b}$. However, the $\mathrm{NO}$ conversion of the $\mathrm{A}-\mathrm{NO}_{3}$ sample exceeds $90 \%$ ranging from 140 to $620^{\circ} \mathrm{C}$ and just declines a little at the temperature range of $240-600{ }^{\circ} \mathrm{C}$.

Figure $1 \mathrm{c}, \mathrm{d}$ shows that the ammonia oxidation ability of the fresh and aged $\mathrm{Cu}^{\mathrm{II}}-\mathrm{SSZ}-13$ catalysts is almost the same over below $300{ }^{\circ} \mathrm{C}$. The stoichiometric relationship between ammonia and $\mathrm{NO}_{\mathrm{x}}$ conversion is 1:1 indicating that standard SCR occurs at this temperature range. However, at the high temperature range, the ammonia conversion rate is significantly higher than the $\mathrm{NO}_{\mathrm{x}}$ conversion rate, indicating that the ammonia oxidation reaction has occurred $[25,26]$.

The three fresh catalysts exhibit $100 \% \mathrm{~N}_{2}$ selectivity in the range of $100-200{ }^{\circ} \mathrm{C}$ and $440-700{ }^{\circ} \mathrm{C}$ as shown in Figure 1d. While, $\mathrm{F}-\mathrm{NO}_{3}$ sample has the lowest $\mathrm{N}_{2} \mathrm{O}$ yield $(<15 \mathrm{ppm})$ among the three samples. Moreover, the amounts of $\mathrm{N}_{2} \mathrm{O}$ produced in all aged $\mathrm{Cu}^{\mathrm{II}}-\mathrm{SSZ}-13$ catalysts are obviously decreased after $300{ }^{\circ} \mathrm{C}$ (Figure 1e). The $\mathrm{A}-\mathrm{NO}_{3}$ sample has lower $\mathrm{N}_{2} \mathrm{O}$ production $(<12 \mathrm{ppm}$ ), and shows $100 \% \mathrm{~N}_{2}$ selectivity in the range of $100-180{ }^{\circ} \mathrm{C}$ and $340-700{ }^{\circ} \mathrm{C}$. The high $\mathrm{N}_{2}$ selectivity of $\mathrm{Cu}^{\mathrm{II}}-\mathrm{SSZ}-13$ catalysts is affected by the type of molecular sieve structure and ammonia oxidation ability $[10,27]$. The formation of $\mathrm{N}_{2} \mathrm{O}$ is mainly related to $\mathrm{NO}_{x}$ reacting with proton-adsorbed $\mathrm{NH}_{3}$ in which $\mathrm{NH}_{4} \mathrm{NO}_{3}$ that forms on protonic sites could slowly decompose [28].
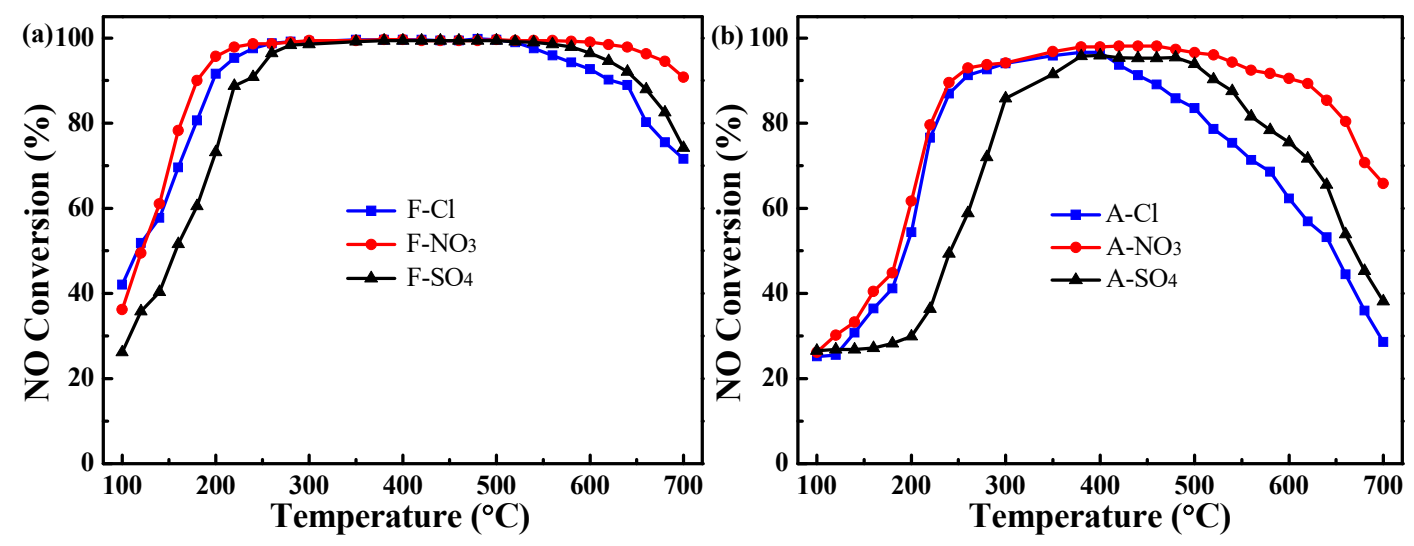

Figure 1. Cont. 

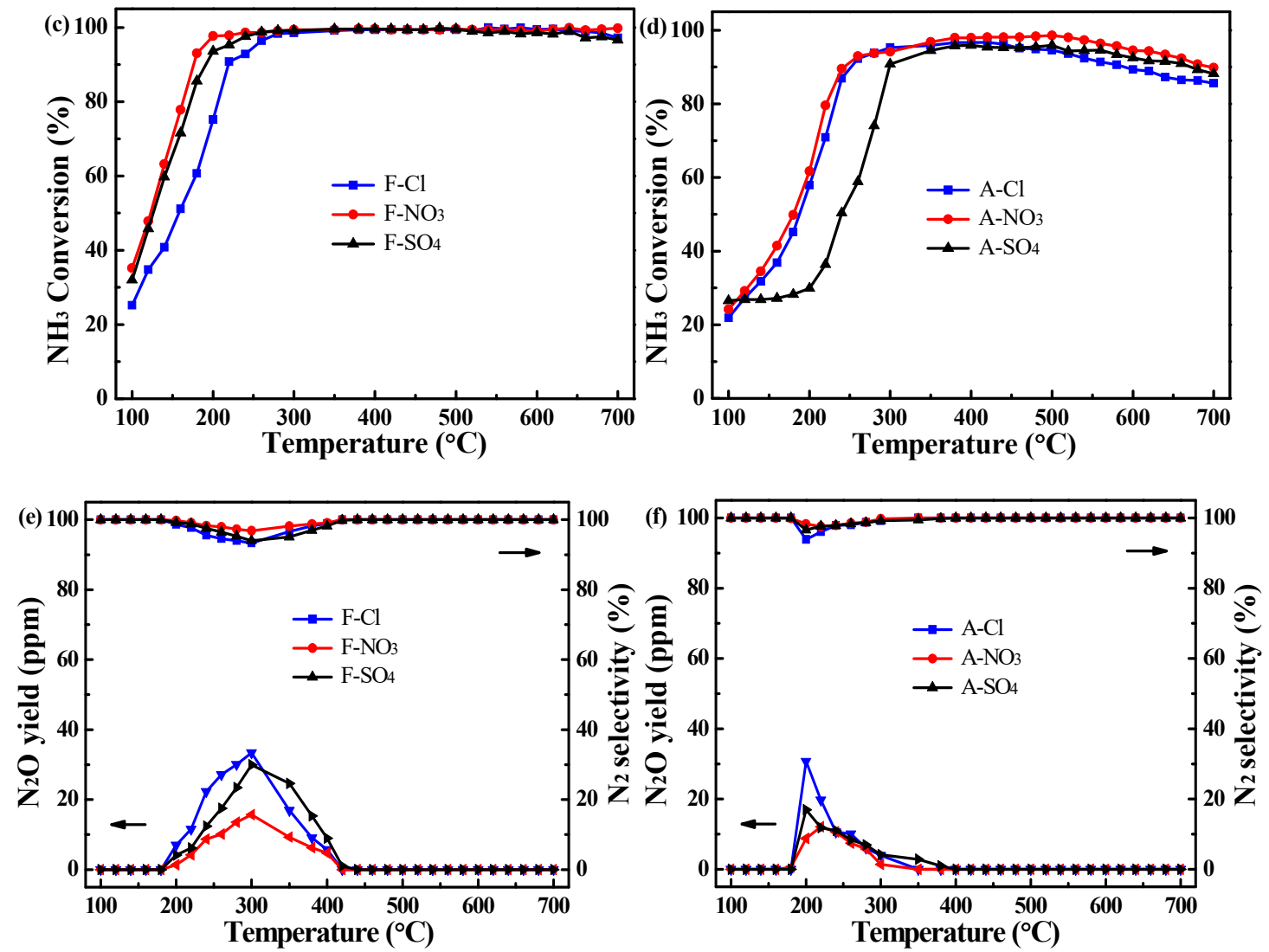

Figure 1. NO conversion $(\mathbf{a}, \mathbf{b}), \mathrm{NH}_{3}$ conversion $(\mathbf{c}, \mathbf{d}), \mathrm{N}_{2}$ selectivity and $\mathrm{N}_{2} \mathrm{O}$ yield $(\mathbf{e}, \mathbf{f})$ of $\mathrm{Cu}{ }^{\mathrm{II}}-\mathrm{SSZ}-13$ catalysts before and after hydrothermal aging treatment. (Feed gas: $0.05 \% \mathrm{NO}, 0.05 \% \mathrm{NH}_{3}, 5 \% \mathrm{O}_{2}$, $10 \% \mathrm{H}_{2} \mathrm{O}$, He balance, gaseous hourly space velocity $(\mathrm{GHSV})=40,000 \mathrm{~h}^{-1}$ ).

\subsection{Structure and Morphology}

\subsubsection{X-ray Diffraction (XRD) Results}

The X-ray diffraction (XRD) results of all $\mathrm{Cu}^{\mathrm{II}}-\mathrm{SSZ}-13$ catalysts are shown in Figure $\mathrm{S} 1$. The fresh and aged samples exhibit characteristic diffraction peaks of SSZ-13 at $2 \theta=9.5^{\circ}, 14.0^{\circ}, 16.1^{\circ}, 17.8^{\circ}, 20.7^{\circ}$, $25.0^{\circ}, 30.7^{\circ}[2,29,30]$. The fresh samples show perfect crystal structure and high crystallinity, among which the peaks of the $\mathrm{F}-\mathrm{Cl}$ sample is stronger than that of $\mathrm{F}-\mathrm{NO}_{3}$ and $\mathrm{F}-\mathrm{SO}_{4}$ samples (Figure S1a). It can be inferred that the copper precursors can affect the crystallinity and regularity of the fresh samples. No distinct diffraction peaks can be observed for the $\mathrm{A}-\mathrm{SO}_{4}$ sample (Figure $\mathrm{S} 1 \mathrm{~b}$ ), which means that the crystal structure of the $\mathrm{A}-\mathrm{SO}_{4}$ sample is severely destroyed. The $\mathrm{Cu}^{\mathrm{II}}-\mathrm{SSZ}-13$ prepared by the $\mathrm{Cu}{ }^{\mathrm{II}}\left(\mathrm{NO}_{3}\right)_{2}$ sample has the smallest change of characteristic peak after aging, which means the hydrothermal stability of these samples are the best. However, there are no diffraction peaks of $\mathrm{CuO}$ observed before and after hydrothermal aging. It means that the $\mathrm{Cu}$ content is low, or the $\mathrm{Cu}$ species are well-dispersed [4].

The grain size parameters with scanning angle near $20^{\circ}$ for all $\mathrm{Cu}^{\mathrm{II}}-\mathrm{SSZ}-13$ catalysts are shown in Table 1. The particle size of $\mathrm{F}-\mathrm{SO}_{4}$ and $\mathrm{F}-\mathrm{Cl}$ samples are 31.21 and $30.51 \mathrm{~nm}$, respectively, while that of $\mathrm{F}-\mathrm{NO}_{3}$ sample is $27.93 \mathrm{~nm}$. It indicated that $\mathrm{F}-\mathrm{NO}_{3}$ sample has small grains, which may be due to the fact that adsorption capacity of $\mathrm{NO}_{3}{ }^{-}$anions on cationic is much larger than those of the $\mathrm{SO}_{4}{ }^{2-}$ and $\mathrm{Cl}^{-}$anions. $\mathrm{NO}_{3}{ }^{-}$ions easily lose water molecules in the process of crystallization or directly utilize water molecules to dissolve other substances on the interface. Its large molecular weight has little effect on surface active agent charge, leading to form small spherical micelles and finally generate small SSZ-13 grain size. The $\mathrm{SO}_{4}{ }^{2-}$ ions frequently lead to a higher surface tension and a salting-out effect (aggregation of cations), which may influence the entering of copper ions to the pores of SSZ-13 
and gathering on the support surface [23]. After aging, the diameter size of all the samples reduced. The grain parameters of the sample $\mathrm{A}-\mathrm{SO}_{4}$ was not calculated because there are no obvious diffraction peaks observed over the scanning angle from $5^{\circ}$ to $50^{\circ}$. The particle size of the $\mathrm{A}-\mathrm{NO}_{3}$ and $\mathrm{A}-\mathrm{Cl}$ samples are 23.64 and $27.19 \mathrm{~nm}$, respectively. It shows that the grain size of the $\mathrm{A}-\mathrm{NO}_{3}$ sample is also the smallest. The grain size of the $\mathrm{F}-\mathrm{Cl}$ sample decreases to a smaller extent after aging, which can be used to explain why the $\mathrm{Cu}^{\mathrm{II}}\left(\mathrm{NO}_{3}\right)_{2}$ sample has strong anti-aging ability.

Table 1. Grain size parameters of $\mathrm{Cu}$ II-SSZ-13 catalysts before and after hydrothermal aging treatment.

\begin{tabular}{ccccc}
\hline Samples & Angle $\left({ }^{\circ}\right)$ & FWHM & Diameter $(\mathbf{n m})$ & Area $\left(\mathbf{m}^{\mathbf{2}}\right)$ \\
\hline $\mathrm{F}-\mathrm{Cl}$ & 20.93 & 0.26 & 30.51 & 3024 \\
$\mathrm{~A}-\mathrm{Cl}$ & 20.96 & 0.29 & 27.19 & 1925 \\
$\mathrm{~F}-\mathrm{NO}$ & 20.69 & 0.29 & 27.93 & 2620 \\
$\mathrm{~A}-\mathrm{NO}_{3}$ & 20.87 & 0.34 & 23.64 & 1761 \\
$\mathrm{~F}-\mathrm{SO}_{4}$ & 20.69 & 0.26 & 31.21 & 2639 \\
$\mathrm{~A}-\mathrm{SO}_{4}$ & - & - & - & - \\
\hline
\end{tabular}

\subsection{2. $\mathrm{N}_{2}$ Adsorption Results}

In order to investigate the effect of different copper precursors on the pore structure of $\mathrm{Cu}^{\mathrm{II}}-\mathrm{SSZ}-13$, $\mathrm{Cu}^{\mathrm{II}}\left(\mathrm{NO}_{3}\right)_{2}, \mathrm{Cu}^{\mathrm{II}} \mathrm{SO}_{4}$ and $\mathrm{Cu}^{\mathrm{II}} \mathrm{Cl}_{2}$ samples were selected for structural analysis. The results are shown in Table 2. The specific surface areas of $\mathrm{F}^{-\mathrm{NO}_{3}}$ and $\mathrm{F}-\mathrm{Cl}$ samples are more than $300 \mathrm{~m} / \mathrm{g}$, while that of $\mathrm{F}-\mathrm{SO}_{4}$. sample is only $233.44 \mathrm{~m}^{2} / \mathrm{g}$. The pore volume and pore size of the $\mathrm{F}-\mathrm{Nit}$. sample are $0.13 \mathrm{~cm}^{3} / \mathrm{g}$ and $0.65 \mathrm{~nm}$, respectively. After aging, the specific surface area of all samples reduced to varying degrees. The specific surface area and pore volume of the $\mathrm{A}-\mathrm{SO}_{4}$ sample decrease significantly, which is consistent with SSZ-13 peaks disappearance in the XRD. The pore volume and pore size of the $\mathrm{A}-\mathrm{NO}_{3}$ and $\mathrm{A}-\mathrm{Cl}$ samples are slightly reduced. It indicates that the $\mathrm{Cu}\left(\mathrm{IIO}_{3}\right)_{2}$ and $\mathrm{Cu}^{\mathrm{II}} \mathrm{Cl}_{2}$ samples are beneficial to strengthen the stability of the molecular sieve catalyst framework structure, and improve the anti-aging properties of the catalysts. Moreover, the pore size of the $\mathrm{Cu}^{\mathrm{II}}\left(\mathrm{NO}_{3}\right)_{2}$ sample before and after aging are the smallest, showing that it has an excellent shape-selective role during the process of gas reaction.

Table 2. Pore structure results of $\mathrm{Cu}^{\mathrm{II}}-\mathrm{SSZ}-13$ catalysts before and after hydrothermal aging treatment.

\begin{tabular}{cccc}
\hline Samples & $\mathbf{S}_{\text {BET }}\left(\mathbf{m}^{2} / \mathbf{g}\right)$ & $\mathbf{V}\left(\mathbf{c m}^{\mathbf{3}} / \mathbf{g}\right)$ & $\mathbf{D}(\mathbf{n m})$ \\
\hline $\mathrm{F}-\mathrm{Cl}$ & 363.99 & 0.15 & 0.77 \\
$\mathrm{~A}-\mathrm{Cl}$ & 242.15 & 0.10 & 0.67 \\
$\mathrm{~F}-\mathrm{NO}_{3}$ & 301.64 & 0.13 & 0.65 \\
$\mathrm{~A}-\mathrm{NO}_{3}$ & 145.84 & 0.08 & 0.56 \\
$\mathrm{~F}-\mathrm{SO}_{4}$ & 233.44 & 0.12 & 1.07 \\
$\mathrm{~A}-\mathrm{SO}_{4}$ & 11.64 & 0.01 & 0.49 \\
\hline
\end{tabular}

\subsubsection{Scanning Electron Microscope (SEM) Results}

Figure 2 shows scanning electron microscope (SEM) pictures of $\mathrm{Cu}^{\mathrm{II}}-\mathrm{SSZ}-13$ catalysts before and after aging. The grain size of $\mathrm{F}-\mathrm{SO}_{4}$ and $\mathrm{F}-\mathrm{Cl}$ samples are relatively large and gather together in clusters. However, the $\mathrm{F}-\mathrm{NO}_{3}$ sample presents a neat and angular cubic crystal grain size, large quantity, and good dispersion. Furthermore, the grain sizes of the entire sample are damaged after aging. The $\mathrm{A}-\mathrm{SO}_{4}$ and $\mathrm{A}-\mathrm{Cl}$ samples have no obvious cubic grain size. The agglomeration phenomenon is very serious. Although the grain size of the $\mathrm{Cu}^{\mathrm{II}}\left(\mathrm{NO}_{3}\right)_{2}$ sample is slightly damaged, it can still maintain complete cubic shape and relatively uniform distribution.

To sum up, during the process of crystal nucleus growth, the adsorption capacity of different anions on the template micelles is very different due to the effect of Hofmeister anion effects, which has 
a direct impact on the formation and growth of crystal grain [23]. It causes the diverse skeletal-structure properties of $\mathrm{Cu}^{\mathrm{II}}-\mathrm{SSZ}-13$, thereby making the catalyst form different morphologies.
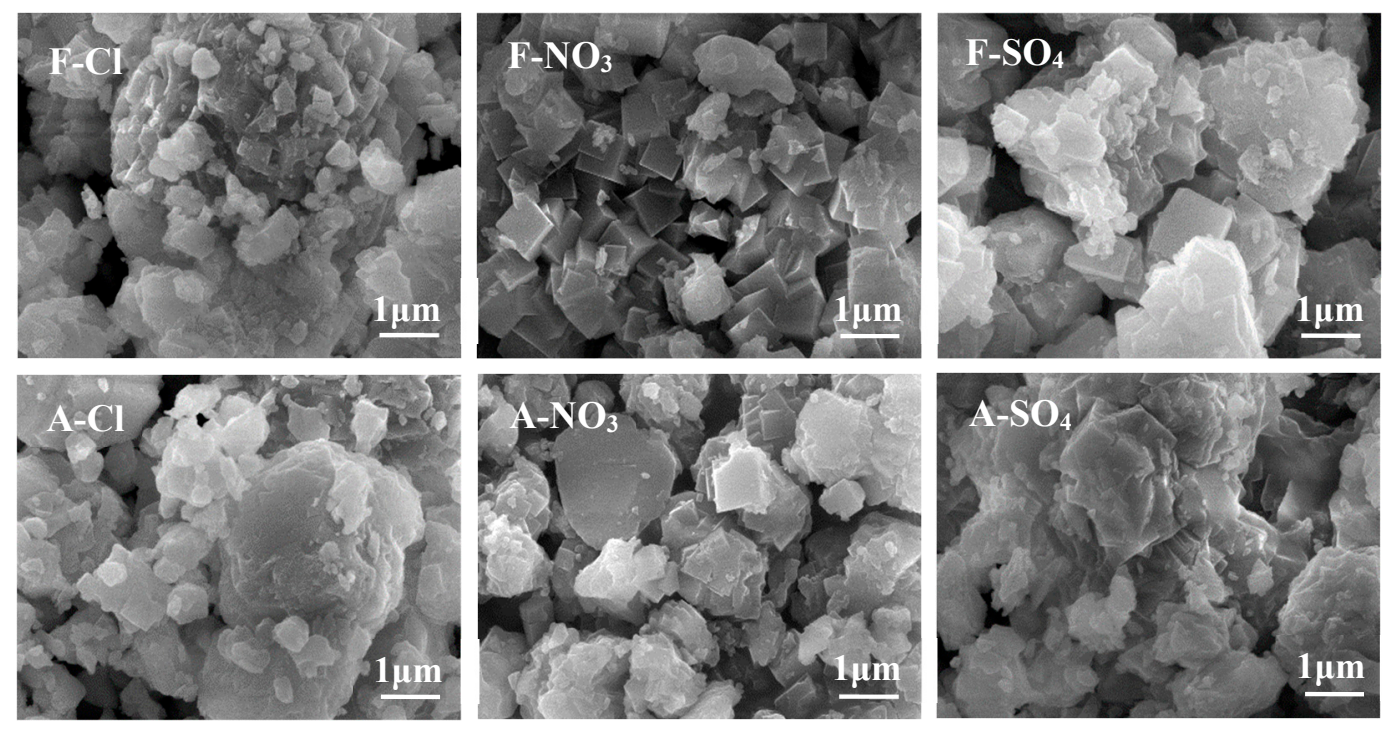

Figure 2. Scanning electron microscope (SEM) images of $\mathrm{Cu}^{\mathrm{II}}-\mathrm{SSZ}-13$ catalysts before and after hydrothermal aging treatment.

\subsubsection{Hydrogen-Temperature-Programmed Reduction $\left(\mathrm{H}_{2}-\mathrm{TPR}\right)$ Results}

The hydrogen-temperature-programmed reduction $\left(\mathrm{H}_{2}-\mathrm{TPR}\right)$ profiles of $\mathrm{Cu}^{\mathrm{II}}-\mathrm{SSZ}-13$ catalysts are displayed in Figure 3. It can be seen that the copper precursors have a significant effect on the distribution of $\mathrm{Cu}$ species in $\mathrm{Cu}^{\mathrm{II}}-\mathrm{SSZ}-13$. There are several types of cationic sites in CHA: in [31-33] the $\mathrm{H}_{2}$ reduction peaks at $180-200$ and $200-280{ }^{\circ} \mathrm{C}$ stand for the reduction of isolated $\mathrm{Cu}^{\mathrm{II}}$ ions to $\mathrm{Cu}^{\mathrm{I}}$ ions in the eight ring and CHA cages, respectively; the $\mathrm{H}_{2}$ reduction peaks at $280-500{ }^{\circ} \mathrm{C}$ are assigned to the reduction of the stable $\mathrm{Cu}^{\mathrm{II}}$ in double six-rings. The reduction peaks of $500-1000{ }^{\circ} \mathrm{C}$ are due to the reduction of $\mathrm{Cu}^{\mathrm{I}}$ to $\mathrm{Cu}^{0}$. As shown in Figure 3, the $\mathrm{H}_{2}-\mathrm{TPR}$ process of isolated $\mathrm{Cu}^{\mathrm{II}}$ on $\mathrm{Cu}^{\mathrm{II}}-\mathrm{SSZ}-13$ catalysts are divided into two steps: reduction of $\mathrm{Cu}^{\mathrm{II}} \rightarrow \mathrm{Cu}^{\mathrm{I}}$ at low temperature $\left(<500{ }^{\circ} \mathrm{C}\right)$ and $\mathrm{Cu}^{\mathrm{I}} \rightarrow \mathrm{Cu}^{0}$ at high temperature $\left(>500^{\circ} \mathrm{C}\right)$ [14]. The fresh samples are shown in Figure 3a, the peak at around $240^{\circ} \mathrm{C}$ is assigned to the reduction of isolated $\mathrm{Cu}^{\mathrm{II}} \rightarrow \mathrm{Cu}^{\mathrm{I}}$ in the $\mathrm{CHA}$ cage. Different reduction peaks areas appear at $375{ }^{\circ} \mathrm{C}$, indicating the presence of different isolated $\mathrm{Cu}^{\mathrm{II}}$ ions in the stable six-membered ring. At $500-1000{ }^{\circ} \mathrm{C}$, two different types reduction peaks of $\mathrm{Cu}^{\mathrm{I}}$ into $\mathrm{Cu}^{0}$ appear in three samples, which can be unstable $\mathrm{Cu}^{\mathrm{I}}$ at low temperature $\left(550^{\circ} \mathrm{C}\right)$ and stable $\mathrm{Cu}^{\mathrm{I}}$ at high temperature $\left(850^{\circ} \mathrm{C}\right)[30,34]$.

After hydrothermal aging, the aged sample's $\mathrm{H}_{2}$ reduction peak decrease and move to the higher temperature, indicating the oxidation capacity of $\mathrm{Cu}$ species is weakened (Figure 3b). However, the A- $\mathrm{NO}_{3}$ sample still has significant reduction peaks at 550 and $813^{\circ} \mathrm{C}$. The $\mathrm{H}_{2}$ reduction peak of at $813{ }^{\circ} \mathrm{C}$ represents the reduction of extremely stable $\mathrm{Cu}^{\mathrm{I}}$ ions. It is worth noting that the reduction temperature of this kind of stable $\mathrm{Cu}^{\mathrm{I}}$ ion is when the structure of the molecular sieve begins to collapse [30,34]. This is consistent with the $\mathrm{XRD}$ results. The $\mathrm{A}-\mathrm{NO}_{3}$ sample has higher stable $\mathrm{Cu}^{\mathrm{I}}$ content and therefore it can maintain a stable skeleton structure. The $\mathrm{H}_{2}$ consumption of $\mathrm{Cu}$ species in the fresh and aged catalysts is shown in Table 3, the content of isolated $\mathrm{Cu}^{\mathrm{II}}$ ions in the $\mathrm{F}-\mathrm{NO}_{3}$ and $\mathrm{A}-\mathrm{NO}_{3}$ samples are much higher than the $\mathrm{Cu}^{\mathrm{II}} \mathrm{Cl}_{2}$ and $\mathrm{Cu}^{\mathrm{II}} \mathrm{SO}_{4}$ samples. Due to the destruction of the skeleton structure of the $\mathrm{A}-\mathrm{SO}_{4}$ sample, the amount of $\mathrm{Cu}^{\mathrm{I}}$ is significantly reduced. During the $\mathrm{NH}_{3}-\mathrm{SCR}$ reaction, the catalytic performance of the $\mathrm{Cu}^{\mathrm{II}}-\mathrm{SSZ}-13$ catalysts is determined by the reducibility of active metal species in molecular sieves. Many researchers have shown that isolated $\mathrm{Cu}^{\mathrm{II}}$ ion is the main active component $[35,36]$. Hence, the conversion of $\mathrm{Cu}^{\mathrm{II}}-\mathrm{SSZ}-13$ catalysts will be decreased when the account of isolated $\mathrm{Cu}^{\mathrm{II}}$ ion is lower. Due to the difference of copper precursors, 
anions may affect the distribution of copper species in the samples. The Pauling radium increased in the order of $\mathrm{NO}_{3}{ }^{-}(1.79 \AA) \approx \mathrm{Cl}^{-}(1.80 \AA)<\mathrm{SO}_{4}{ }^{2-}(2.30 \AA)$ [23]. Larger anions from the copper precursors can inhibit the entering of copper ions into the SSZ-13 pore during the formation of the colloidal process. However, the copper ions from the precursors with small anions ions like $\mathrm{NO}_{3}{ }^{-}$ are more accessible to enter the pore, which generates more isolated $\mathrm{Cu}^{\mathrm{II}}$, and exhibits excellent $\mathrm{NH}_{3}-\mathrm{SCR}$ activity.
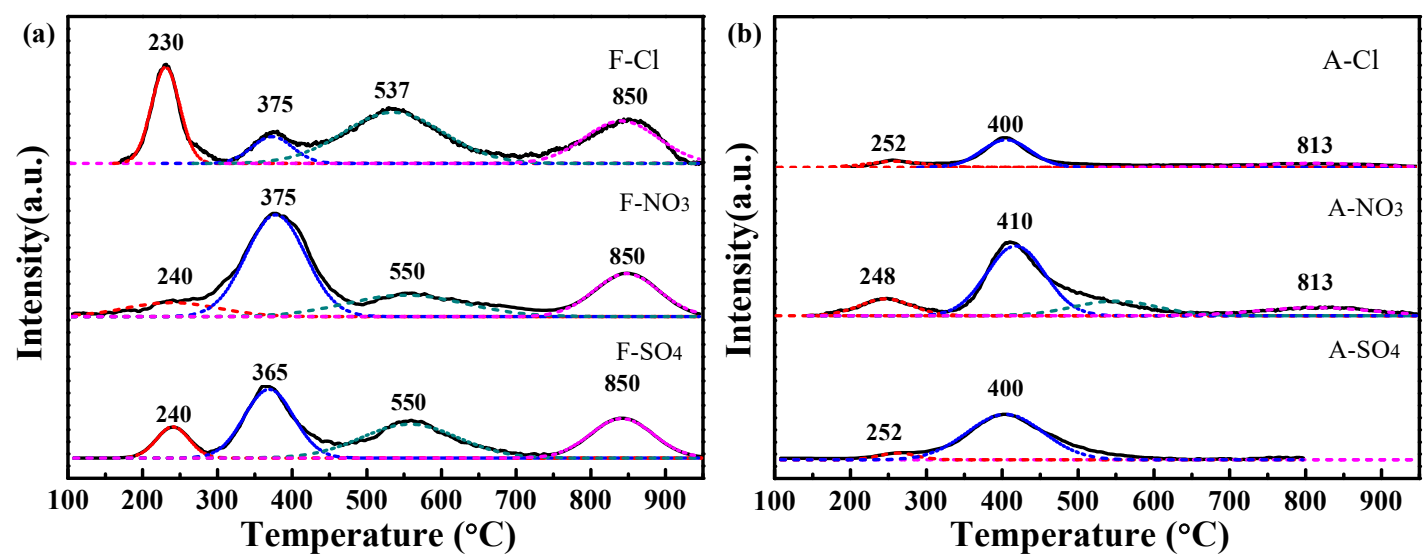

Figure 3. Hydrogen-temperature-programmed reduction $\left(\mathrm{H}_{2}-\mathrm{TPR}\right)$ profiles of $\mathrm{Cu}^{\mathrm{II}}-\mathrm{SSZ}-13$ catalysts before (a) and after (b) hydrothermal aging treatment.

Table 3. $\mathrm{H}_{2}$ consumption of $\mathrm{Cu}^{\mathrm{II}}-\mathrm{SSZ}-13$ catalysts before and after hydrothermal aging treatment.

\begin{tabular}{|c|c|c|c|c|c|}
\hline \multirow[b]{2}{*}{ Samples } & \multicolumn{4}{|c|}{$\mathrm{H}_{2}$ Consumption $\left(\mu \mathrm{mol} \mathrm{g}^{-1}\right)$} & \multirow{2}{*}{$\begin{array}{c}\text { Total } \mathrm{H}_{2} \text { Consumption } \\
\left(\mu \mathrm{mol} \mathrm{g}^{-1}\right)\end{array}$} \\
\hline & $\begin{array}{c}\mathrm{Cu}^{\mathrm{II}} \rightarrow \mathrm{Cu}^{\mathrm{I}} \\
(\mathrm{CHA} \text { Cages })\end{array}$ & $\begin{array}{l}\mathrm{Cu}^{\mathrm{II}} \rightarrow \mathrm{Cu} \mathbf{u}^{\mathrm{I}} \\
\quad(\mathrm{D} 6 \mathrm{R})\end{array}$ & $\begin{array}{l}\mathrm{Cu} \mathbf{u}^{\mathrm{II}} \rightarrow \mathrm{Cu}{ }^{\mathrm{I}} \\
\quad(\text { Total) }\end{array}$ & $\mathrm{Cu} \mathbf{u}^{\mathrm{I}} \rightarrow \mathrm{Cu}^{0}$ & \\
\hline $\mathrm{F}-\mathrm{Cl}$ & 53.69 & 28.71 & 82.40 & 163.34 & 245.74 \\
\hline $\mathrm{A}-\mathrm{Cl}$ & 4.32 & 25.56 & 29.88 & 32.89 & 62.77 \\
\hline $\mathrm{F}-\mathrm{NO}_{3}$ & 34.75 & 136.46 & 171.21 & 152.76 & 323.97 \\
\hline $\mathrm{A}-\mathrm{NO}_{3}$ & 25.74 & 111.43 & 137.17 & 79.50 & 216.67 \\
\hline $\mathrm{F}-\mathrm{SO}_{4}$ & 28.61 & 87.35 & 115.96 & 133.87 & 249.83 \\
\hline $\mathrm{A}-\mathrm{SO}_{4}$ & 4.17 & 58.48 & 62.65 & 0 & 62.65 \\
\hline
\end{tabular}

\subsubsection{Ammonia Temperature-Programmed Desorption ( $\left.\mathrm{NH}_{3}-\mathrm{TPD}\right)$ Results}

The acid sites of the molecular sieve catalyst are beneficial to adsorption and activation of $\mathrm{NH}_{3}$, which is one of the key steps for the reduction of $\mathrm{NO}$ by $\mathrm{NH}_{3}$ molecules [2,37]. The ammonia temperature-programmed desorption $\left(\mathrm{NH}_{3}-\mathrm{TPD}\right)$ spectra of the $\mathrm{Cu}{ }^{\mathrm{II}}-\mathrm{SSZ}-13$ catalysts are shown in Figure 4. The peak at $130^{\circ} \mathrm{C}$ (Peak A) and $168^{\circ} \mathrm{C}($ Peak B) are attributed to the physical adsorption and weakly adsorbed $\mathrm{NH}_{3}$ on the weak Lewis acid sites, respectively $[38,39]$. The peaks at $258{ }^{\circ} \mathrm{C}$ (Peak C) and above $420^{\circ} \mathrm{C}$ (Peak D) belong to $\mathrm{NH}_{3}$ adsorbed on strong Lewis acid sites originating from the isolated $\mathrm{Cu}^{\mathrm{II}}$ ions and $\mathrm{NH}_{3}$ adsorbed on Brønsted acid sites, respectively. Table 4 shows the adsorption amounts of $\mathrm{NH}_{3}$ on the fresh and aged samples by deconvolution of the $\mathrm{NH}_{3}-\mathrm{TPD}$ curves. The total acid amounts of all fresh samples are similar. Additionally, the adsorption amount of ammonia decreases and the ammonia oxidation reaction has occurred during temperature increase, causing the activity of the catalyst to decrease. After hydrothermal aging, the $\mathrm{NH}_{3}$ adsorption peaks all decreased due to the destruction of the $\mathrm{CHA}$ structure and the loss of the isolated $\mathrm{Cu}^{\mathrm{II}}$ ions, which is demonstrated by the results of $\mathrm{H}_{2}-\mathrm{TPR}$ and XRD characterization. Many studies have shown that the chemisorption of $\mathrm{NH}_{3}$ plays a significant role in the $\mathrm{NH}_{3}-\mathrm{SCR}$ performance $[2,30,40]$. 

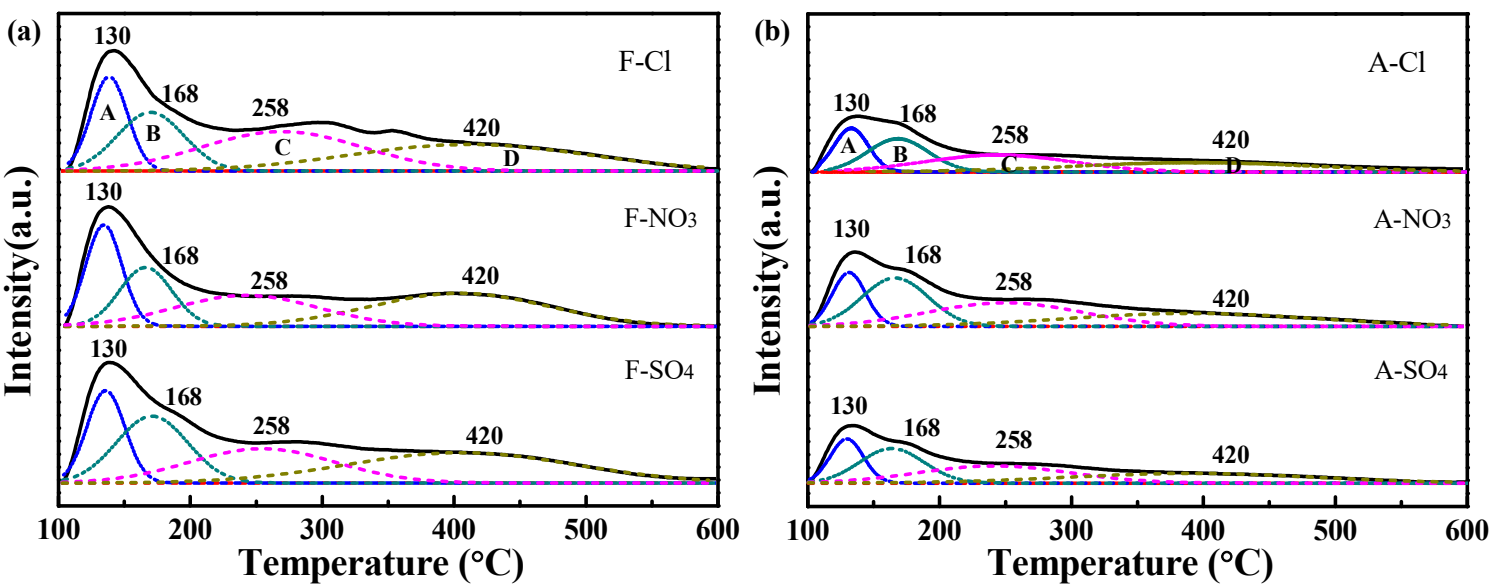

Figure 4. Ammonia temperature-programmed desorption $\left(\mathrm{NH}_{3}-\mathrm{TPD}\right)$ profiles of $\mathrm{Cu}{ }^{\mathrm{II}}-\mathrm{SSZ}-13$ catalysts before (a) and after (b) hydrothermal aging treatment.

Table 4. The adsorbed $\mathrm{NH}_{3}$ amount of $\mathrm{Cu}^{\mathrm{II}}-\mathrm{SSZ}-13$ catalysts before and after hydrothermal aging treatment.

\begin{tabular}{|c|c|c|c|c|c|}
\hline \multirow[b]{2}{*}{ Samples } & \multicolumn{4}{|c|}{ Adsorbed $\mathrm{NH}_{3}$ Amount $\left(\mathrm{mmol} \mathrm{g}^{-1}\right)$} & \multirow{2}{*}{$\begin{array}{l}\text { Total Amount } \\
\left(\mathrm{mmol} \mathrm{g}^{-1}\right)\end{array}$} \\
\hline & $\begin{array}{c}\text { Physical } \\
\text { Adsorption }\end{array}$ & $\begin{array}{c}\text { Weak Lewis } \\
\text { Acid Sites }\end{array}$ & $\begin{array}{l}\text { Strong Lewis } \\
\text { Acid Sites }\end{array}$ & $\begin{array}{l}\text { Brønsted } \\
\text { Acid Sites }\end{array}$ & \\
\hline $\mathrm{F}-\mathrm{Cl}$ & 0.18 & 0.23 & 0.33 & 0.45 & 1.19 \\
\hline $\mathrm{A}-\mathrm{Cl}$ & 0.08 & 0.10 & 0.17 & 0.21 & 0.56 \\
\hline $\mathrm{F}-\mathrm{NO}_{3}$ & 0.20 & 0.21 & 0.32 & 0.54 & 1.27 \\
\hline $\mathrm{A}-\mathrm{NO}_{3}$ & 0.14 & 0.19 & 0.21 & 0.28 & 0.82 \\
\hline $\mathrm{F}-\mathrm{SO}_{4}$ & 0.18 & 0.23 & 0.31 & 0.47 & 1.19 \\
\hline $\mathrm{A}-\mathrm{SO}_{4}$ & 0.09 & 0.11 & 0.16 & 0.23 & 0.59 \\
\hline
\end{tabular}

\subsubsection{X-ray Photoelectron Spectroscopy (XPS) Results}

The $\mathrm{Cu}^{\mathrm{II}}-\mathrm{SSZ}-13$ catalysts are analyzed by $\mathrm{Cu}_{2 p} \mathrm{X}$-ray photoelectron spectroscopy (XPS) in Figure 5. The fresh and aged samples have a main peak and a satellite peak of $\mathrm{Cu} 2 \mathrm{p}_{3 / 2}(930-939$ and 940-948 eV) and $\mathrm{Cu} 2 \mathrm{p}_{1 / 2}(950-955$ and $960.0-968 \mathrm{eV})$. The $\mathrm{Cu} 2 \mathrm{p}_{3 / 2}$ peaks at $935.9 \mathrm{eV}$ are attributed to the isolated $\mathrm{Cu}^{\mathrm{II}}$ species. The characteristic peak at $933.2 \mathrm{eV}$ is ascribed to the $\mathrm{Cu}^{\mathrm{I}}$ species [41,42].

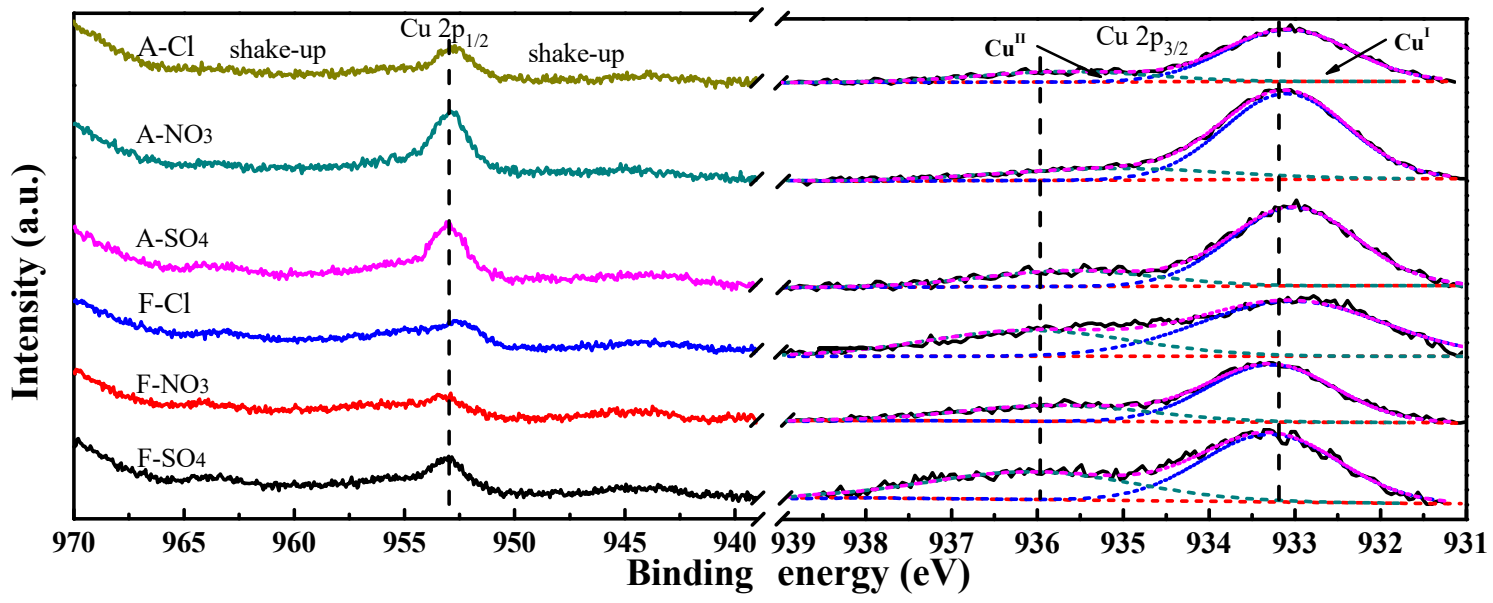

Figure 5. $\mathrm{Cu} 2 \mathrm{p}$ XPS spectra of $\mathrm{Cu}^{\mathrm{II}}-\mathrm{SSZ}-13$ catalysts before and after hydrothermal aging treatment.

The $\mathrm{Cu}^{\mathrm{II}} / \mathrm{Cu}_{\text {sur }}$ ratios of all fresh sample are reduced after aging as shown in Table 5 . The isolated $\mathrm{Cu}^{\mathrm{II}}$ species facilitate the reduction of $\mathrm{NO}_{\mathrm{x}}$ at low temperature, which trigger the decrease of catalytic 
activity of the aged samples [37]. The $\mathrm{Cu}$ and $\mathrm{Al}$ contents of the $\mathrm{A}-\mathrm{SO}_{4}$ sample increase significantly and can be due to the serious destruction of the framework. However, the $\mathrm{Cu}$ and $\mathrm{Al}$ contents of $\mathrm{A}-\mathrm{Cl}$ sample decrease obviously. According to the results of the ${ }^{27} \mathrm{Al}$ Nuclear Magnetic Resonance (NMR) spectra, the signal invisible of octahedral aluminum ions in the fresh and aged catalysts prepared by $\mathrm{Cu}^{\mathrm{II}} \mathrm{Cl}_{2}$ is because that paramagnetic $\mathrm{Cu}$ ions may interact more strongly with the forming octahedral aluminum, which cause the decrease of surface $\mathrm{Cu}$ and $\mathrm{Al}$ species $[10,43]$. Furthermore, the change in XPS curve of $\mathrm{Cu}^{\mathrm{II}}\left(\mathrm{NO}_{3}\right)_{2}$ sample is the least before and after aging. The Si/Al decreases slightly on the surface after aging, which may be due to aging inducing slight de-alumination. Therefore, a small portion of aluminum migrates to the surface, which maintains good anti-aging properties of the skeleton structure.

Table 5. $\mathrm{Cu} 2 \mathrm{p}_{3 / 2}$ XPS curve-fitting results of $\mathrm{Cu}^{\mathrm{II}}-\mathrm{SSZ}-13$ catalysts before and after hydrothermal aging treatment.

\begin{tabular}{|c|c|c|c|c|c|c|}
\hline Samples & $\mathrm{Cu} u_{\text {sur }}(w t \%)$ & $\mathrm{Cu}^{\mathrm{II}} / \mathrm{Cu}_{\text {sur }}$ & $\mathrm{Cu}^{\mathrm{II}} / \mathrm{Cu}{ }^{\mathrm{I}}$ & $\mathrm{Si}_{\text {sur }}(w \mathrm{t} \%)$ & $A l_{\text {sur }}(w t \%)$ & $\mathrm{Si} / \mathrm{Al}_{\text {sur }}$ \\
\hline $\mathrm{F}-\mathrm{Cl}$ & 0.56 & 0.44 & 0.63 & 6.59 & 3.42 & 1.93 \\
\hline $\mathrm{A}-\mathrm{Cl}$ & 0.29 & 0.15 & 0.35 & 6.30 & 2.66 & 2.37 \\
\hline $\mathrm{F}-\mathrm{NO}_{3}$ & 0.34 & 0.30 & 0.61 & 6.36 & 2.44 & 2.61 \\
\hline $\mathrm{A}-\mathrm{NO}_{3}$ & 0.57 & 0.17 & 0.39 & 6.66 & 2.95 & 2.26 \\
\hline $\mathrm{F}-\mathrm{SO}_{4}$ & 0.26 & 0.38 & 0.52 & 6.94 & 2.50 & 2.78 \\
\hline $\mathrm{A}-\mathrm{SO}_{4}$ & 0.77 & 0.24 & 0.35 & 6.65 & 3.36 & 1.98 \\
\hline
\end{tabular}

\subsubsection{NMR Results}

In order to further study the effects of different copper precursors on the chemical environment of $\mathrm{Si}$ and $\mathrm{Al}$ in $\mathrm{Cu}^{\mathrm{II}}-\mathrm{SSZ}-13$ catalysts, and the effect of hydrothermal aging treatment, ${ }^{29} \mathrm{Si} \mathrm{NMR}$ and ${ }^{27} \mathrm{Al} \mathrm{NMR}$ were performed for the fresh and aged catalysts. It can be seen from the ${ }^{27} \mathrm{Al}$ NMR spectra of Figure $6 \mathrm{a}-\mathrm{c}$ that fresh samples show significant $\mathrm{Al}^{3+}$ tetrahedral coordination framework features that appear at $\sim 58.7 \mathrm{ppm}[10,11]$. The $\mathrm{F}-\mathrm{SO}_{4}$ and $\mathrm{F}-\mathrm{NO}_{3}$ show one relatively small new resonance peak at $-1.3 \mathrm{ppm}$, which come down the extra-framework $\mathrm{Al}$ in octahedral [44]. It is worth noting that hydrothermal aging at $800{ }^{\circ} \mathrm{C}$ for $20 \mathrm{~h}$ can result in some tetrahedral aluminum transferred into penta-coordinated extra-framework aluminum structure. The resonance peak at $-1.3 \mathrm{ppm}$ almost disappears. Note also that the portion of Al detached from the molecular sieve framework does not appear at $\sim-1.3 \mathrm{ppm}$. This portion of $\mathrm{Al}$ stays adjacent to paramagnetic $\mathrm{Cu}$ sites and thus invisible to NMR $[43,45]$. To better compare the changes of the $\mathrm{Al}$ coordination structure before and after the hydrothermal aging treatment, the tetrahedral $\mathrm{Al}$ signal area of the fresh sample is taken as a unity. The amount of framework $\mathrm{Al}$ in the aged sample is normalized to reveal the dealumination during the hydrothermal treatment. The proportion of tetrahedral $\mathrm{Al}$ in $\mathrm{A}-\mathrm{Cl}$ sample is 0.74 indicating evident dealumination. In addition, the $\mathrm{A}-\mathrm{SO}_{4}$ sample has the strongest pentacoordinated extra-framework aluminum structure resonance peak. The proportion of tetrahedral $\mathrm{Al}$ is 0.85 . However, the resonance peak intensity of $\mathrm{Al}^{3+}$ tetrahedral coordination structure of the A-Nit. sample at $58.7 \mathrm{ppm}$ is sharper. The proportion of tetrahedral $\mathrm{Al}$ in $\mathrm{A}-\mathrm{NO}_{3}$ sample is 0.94 , which means that the hydrothermal aging process causes little damage to the $\mathrm{Cu}\left(\mathrm{NO}_{3}\right)_{2}$ sample skeleton structure. It is consistent with the results of XRD. The $\mathrm{Cu}^{\mathrm{II}}\left(\mathrm{NO}_{3}\right)_{2}$ sample exhibits slight skeleton dealumination and maintains stable SSZ-13 framework structure. It is further confirmed that the $\mathrm{Cu}^{\mathrm{II}}\left(\mathrm{NO}_{3}\right)_{2}$ sample has better resistance to hydrothermal aging. 

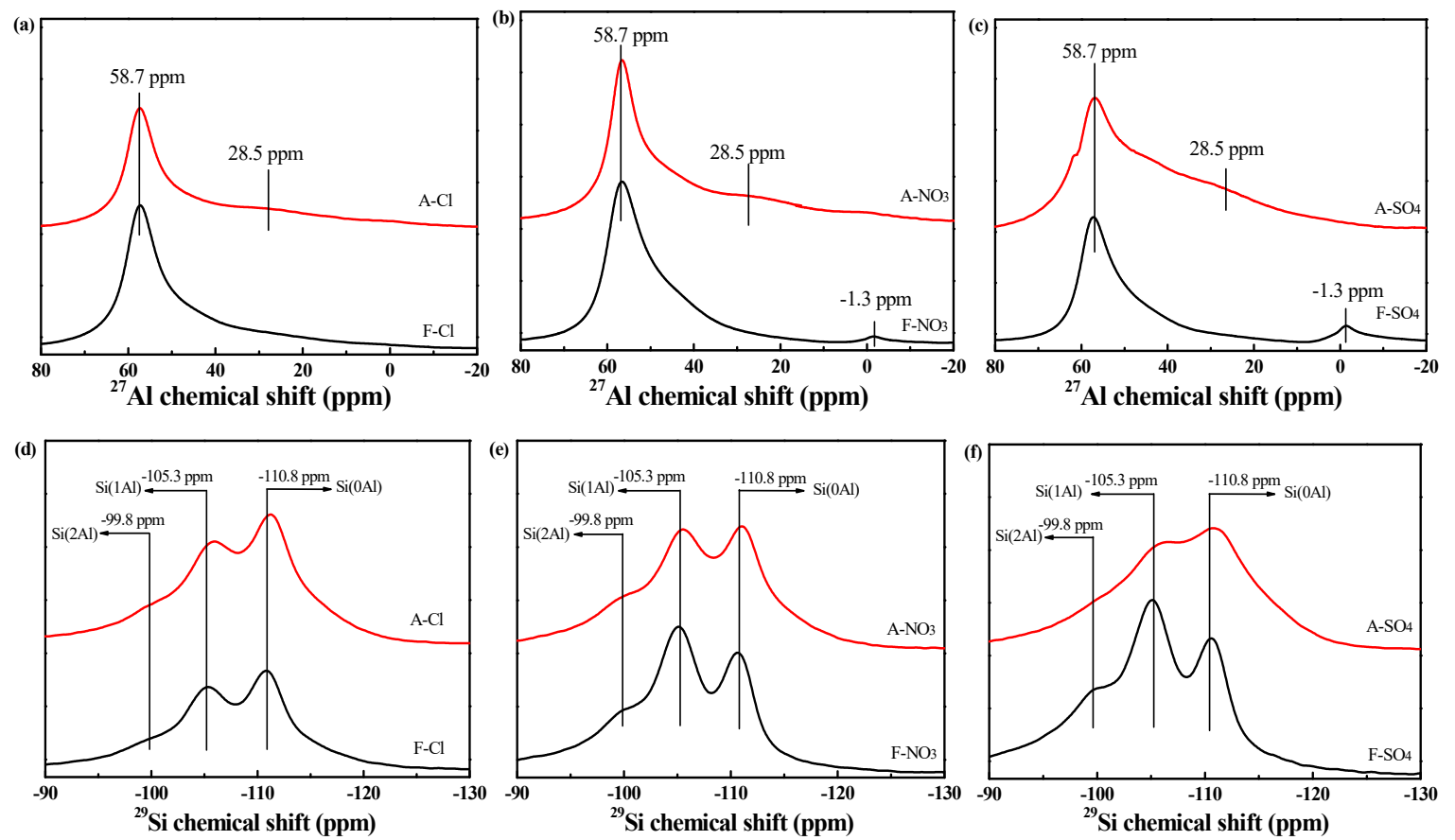

Figure 6. Solid state ${ }^{27} \mathrm{Al}-\mathrm{Nuclear}$ Magnetic Resonance (NMR) (a-c) and ${ }^{29}$ Si-NMR (d-f) spectra of $\mathrm{Cu}^{\mathrm{II}}-\mathrm{SSZ}-13$ catalysts before and after hydrothermal aging treatment.

As seen in Figure $6 \mathrm{~d}-\mathrm{f}$, wide ${ }^{29} \mathrm{Si}-\mathrm{NMR}$ peaks with maxima at $-99.8,-105.3$, and $-110.8 \mathrm{ppm}$ are registered for $\mathrm{Cu}^{\mathrm{II}}-\mathrm{SSZ}-13$ catalysts. These peaks are related to the following types: the structure of $\mathrm{Si}(2 \mathrm{Al})$, the $\mathrm{Si}(1 \mathrm{Al})$, and $\mathrm{Si}(0 \mathrm{Al})[46,47]$. The $\mathrm{F}-\mathrm{NO}_{3}$ sample contains more $\mathrm{Si}(2 \mathrm{Al})$ and $\mathrm{Si}(2 \mathrm{Al})$ and $\mathrm{Si}(1 \mathrm{Al})$ structures. After aging, the peak at $-105.3 \mathrm{ppm}$ of three samples is weakened. The $\mathrm{Si}(1 \mathrm{Al})$ structure of $\mathrm{A}-\mathrm{SO}_{4}$ is severely damaged, and the $\mathrm{F}-\mathrm{Cl}$ sample contains more $\mathrm{Si}(0 \mathrm{Al})$ structure. However, two peaks at 105.3 and $110.8 \mathrm{ppm}$ become similar shoulder peaks for the A-Nit sample. $\mathrm{Si}(1 \mathrm{Al})$ and $\mathrm{Si}(0 \mathrm{Al})$ structures occupy a larger proportion. The catalytic properties of molecular sieves are mainly depending on the skeleton structure and surface acidity. The Si coordination structures have a significant effect on the acid intensity, which is enhanced in the order of $\mathrm{Si}(0 \mathrm{Al})<\mathrm{Si}(4 \mathrm{Al})<$ $\mathrm{Si}(3 \mathrm{Al})<\mathrm{Si}(2 \mathrm{Al})<\mathrm{Si}(1 \mathrm{Al})[4,27,48]$. It is consistent with the results of $\mathrm{NH}_{3}-\mathrm{TPD}$.

\section{Materials and Methods}

\subsection{Catalyst Preparation}

The CuII-SSZ-13 catalysts were prepared by in-situ hydrothermal synthesis method using three kinds of copper precursors $\left(\mathrm{Cu}^{\mathrm{II}}\left(\mathrm{NO}_{3}\right)_{2}, \mathrm{Cu}^{\mathrm{II}} \mathrm{SO}_{4}, \mathrm{Cu}^{\mathrm{II}} \mathrm{Cl}_{2}\right)$. The copper complex $(\mathrm{Cu}-\mathrm{TEPA})$ was used as the template. An appropriate amount of silica sol (30.4\%), sodium metaaluminate (99\%), sodium hydroxide $(96 \%)$, tetraethylenepentamine (TEPA, 95\%), and deionized water, were mixed at the molar ratios of $2.5 \mathrm{Al}_{2} \mathrm{O}_{3}: 2.5 \mathrm{Na}_{2} \mathrm{O}: 7.4 \mathrm{SiO}_{2}: 147.7 \mathrm{H}_{2} \mathrm{O}: 1.47 \mathrm{Cu}-\mathrm{TEPA}[49,50]$. The formed gel was successively transferred into three $100 \mathrm{~mL}$ PTFE (polytetrafluoroethylene) autoclaves and crystallized at $140{ }^{\circ} \mathrm{C}$ for $72 \mathrm{~h}$. The products were washed by deionized water, and dried at $100^{\circ} \mathrm{C}$ for $12 \mathrm{~h}$. Then, the samples was treated by ion exchange with a certain amount of $\mathrm{NH}_{4} \mathrm{NO}_{3}(1 \mathrm{~mol} / \mathrm{L})$ solution for $12 \mathrm{~h}$ at $80^{\circ} \mathrm{C}$. Finally, the samples were calcined at $550{ }^{\circ} \mathrm{C}$ for $8 \mathrm{~h}$. The obtained $\mathrm{Cu}^{\mathrm{II}}-\mathrm{SSZ}-13$ catalyst using $\mathrm{Cu}^{\mathrm{II}} \mathrm{Cl}_{2}$, $\mathrm{Cu}^{\mathrm{II}}\left(\mathrm{NO}_{3}\right)_{2}$, and $\mathrm{Cu}^{\mathrm{II}} \mathrm{SO}_{4}$ solution as precursor were labeled as $\mathrm{F}-\mathrm{Cl}, \mathrm{F}-\mathrm{NO}_{3}$, and $\mathrm{F}-\mathrm{SO}_{4}$, respectively. 


\subsection{Hydrothermal Aging Treatment of Catalysts}

To investigate the hydrothermal stability of the prepared $\mathrm{Cu}^{\mathrm{II}}-\mathrm{SSZ}-13$ catalysts, they were aged in a fixed bed reactor containing $10 \mathrm{vol} \% \mathrm{H}_{2} \mathrm{O}$ under $\mathrm{Ar}$ atmosphere at $800{ }^{\circ} \mathrm{C}$ for $20 \mathrm{~h}$. The aged catalysts were labeled as $\mathrm{A}-\mathrm{Cl}, \mathrm{A}-\mathrm{NO}_{3}$, and $\mathrm{A}-\mathrm{SO}_{4}$, respectively.

\subsection{Catalyst Activity Evaluation}

The catalytic activity was evaluated using a temperature-programmed fixed bed reactor at a gaseous hourly space velocity (GHSV) of $40,000 \mathrm{~h}^{-1}$. As shown in Figure S2, the gaseous hourly space velocity (GHSV) of $40,000 \mathrm{~h}^{-1}$ is preferentially used as the optimal space velocity for the $\mathrm{F}-\mathrm{NO}_{3}$ sample. The reactor contained $0.05 \% \mathrm{NO}, 0.05 \% \mathrm{NH}_{3}, 5 \mathrm{vol} \% \mathrm{O}_{2}$, and $10 \mathrm{vol} \% \mathrm{H}_{2} \mathrm{O}$. He was used as balance gas. The total flow rate $400 \mathrm{~mL} \mathrm{~min}^{-1}$. The concentrations of $\mathrm{NO}, \mathrm{NH}_{3}, \mathrm{~N}_{2} \mathrm{O}$, and $\mathrm{NO}_{2}$ gases were measured in situ by a NICOLET IS10 FTIR spectrometer. The NO conversion and the $\mathrm{N}_{2}$ selectivity were calculated based on the following equation:

$$
\begin{gathered}
X_{\mathrm{NO}}=\frac{C_{\mathrm{NO}, \text { in }}-C_{\mathrm{NO}, \text { out }}}{C_{\mathrm{NO}, \text { out }}} \times 100 \%, \\
S_{\mathrm{N}_{2}}=\left(1-\frac{2 C_{\mathrm{N}_{2} \mathrm{O}, \text { out }}+C_{\mathrm{NO}_{2} \text {, out }}}{C_{\mathrm{NO}, \text { in }}+C_{\mathrm{NH}_{3} \text {, in }}-C_{\mathrm{NO}, \text { out }}-C_{\mathrm{NH}_{3} \text {, out }}}\right) \times 100 \% .
\end{gathered}
$$

\subsection{Catalyst Characterization}

The XRD analysis was carried out on a DX-2700 diffractometer (Dangdong, Dandong Aolong Ray Instrument Group Co., Ltd. China) with $\mathrm{Cu} \mathrm{K} \alpha$ radiation $(\lambda=1.54184 \mathrm{~nm})$ at $40 \mathrm{kV}$ and $30 \mathrm{~mA}$. The dates were collected with a scanning speed of $8^{\circ} \cdot \mathrm{min}^{-1}$ that ranged from $5^{\circ}$ to $60^{\circ}$. The SEM images of samples were obtained via a Japanese Jeol JSM-7001F instrument (JEOL, Japan) at $10 \mathrm{kV}$. $\mathrm{H}_{2}-\mathrm{TPR}$ and $\mathrm{NH}_{3}$-TPD experiments were carried out on the Autochem II 2920 instrument (Micromeritics, Norcross, GA, USA). For $\mathrm{H}_{2}$-TPR measurement, $100 \mathrm{mg}$ of sample was set into a quartz reactor and pretreated at $300^{\circ} \mathrm{C}$ for $0.5 \mathrm{~h}$ in $\mathrm{Ar}$ atmosphere. After cooling to room temperature $\left(25^{\circ} \mathrm{C}\right)$, the gas was switched to a $10 \mathrm{vol} \% \mathrm{H}_{2}-\mathrm{Ar}$ mixture gas with the temperature increased from 50 to $1000{ }^{\circ} \mathrm{C}$ at a rate of $10^{\circ} \mathrm{C} \mathrm{min}{ }^{-1}$. For $\mathrm{NH}_{3}-\mathrm{TPD}$ measurement, the pretreatment was as same as the $\mathrm{H}_{2}-\mathrm{TPR}$ process and then exposed to $10 \% \mathrm{NH}_{3} / \mathrm{He}$ at $50{ }^{\circ} \mathrm{C}$ for $30 \mathrm{~min}$, followed by a temperature ramp to $600{ }^{\circ} \mathrm{C}$ at a rate of $10^{\circ} \mathrm{C} \mathrm{min}^{-1}$. The pore structure analysis of the samples was acquired on a JW-BK122W $\mathrm{N}_{2}$ adsorption-desorption instrument (Beijing, JWGB Sci. \& Tech. Co., Ltd., China) by using liquid nitrogen at $77 \mathrm{~K}\left(-196^{\circ} \mathrm{C}\right)$. XPS measurements were performed on an AXIS ULTRA DLD electron spectrometer (Kratos corporation, UK) with a monochromatic $\mathrm{Al} \mathrm{K} \alpha(\mathrm{hv}=1486.6 \mathrm{eV})$ as excitation source. ${ }^{27} \mathrm{Al}$ and ${ }^{29} \mathrm{Si}$ solid state NMR spectra were collected by an Avance III $600 \mathrm{MHz}$ instrument (Bruker, UK). ${ }^{29} \mathrm{Si}$ MAS NMR spectra were recorded at a rate of $5 \mathrm{kHz}$ and $7 \mathrm{~mm}$ probe. ${ }^{27} \mathrm{Al}$ MAS NMR spectra were recorded at a rate of $13 \mathrm{kHz}$ using a $4 \mathrm{~mm}$ probe.

\section{Conclusions}

In summary, the $\mathrm{Cu}^{\mathrm{II}}-\mathrm{SSZ}-13$ catalysts were prepared by in-situ hydrothermal synthesis method using various copper precursors $\left(\mathrm{Cu}^{\mathrm{II}}\left(\mathrm{NO}_{3}\right)_{2}, \mathrm{Cu}^{\mathrm{II}} \mathrm{SO}_{4}, \mathrm{Cu}^{\mathrm{II}} \mathrm{Cl}_{2}\right)$ for $\mathrm{NO}$ selective catalytic reduction with $\mathrm{NH}_{3}$ in simulated diesel vehicle exhausts. The $\mathrm{Cu}^{\mathrm{II}}\left(\mathrm{NO}_{3}\right)_{2}$ sample not only exhibits outstanding catalytic activity and $\mathrm{N}_{2}$ selectivity, but also has higher anti-aging properties. The $\mathrm{F}-\mathrm{NO}_{3}$ sample exceeded $90 \%$ conversion at a wide range of $180 \sim 700{ }^{\circ} \mathrm{C}$. After aging for $20 \mathrm{~h}$ at $800{ }^{\circ} \mathrm{C}$, the $\mathrm{A}-\mathrm{NO}_{3}$ sample still exhibits above $90 \% \mathrm{NO}$ conversion in the temperature range of $240-600{ }^{\circ} \mathrm{C}$. The difference of deNO $\mathrm{x}_{\mathrm{x}}$ activity and anti-aging performance can be tuned by copper precursor due to the anion's effect. The Pauling radium of the anion affects the distribution of copper species in the $\mathrm{Cu}^{\mathrm{II}}$-SSZ-13 catalyst. The larger anions could impede the entry of copper ions into the pores and gathered on the out surface of the molecular sieve. In addition, the adsorption capacity of different anions to 
the cations will affect the nucleation, and the growth process of SSZ-13 can affect the crystallization process. More isolated $\mathrm{Cu}^{\mathrm{II}}$ ions are adsorbed in the framework of the $\mathrm{Cu}^{\mathrm{II}}-\mathrm{SSZ}-13$ catalyst and served as active sites for the $\mathrm{NH}_{3}-\mathrm{SCR}$ reaction resulting in excellent catalytic activity. Furthermore, after hydrothermal aging treatment, the $\mathrm{Cu}{ }^{\mathrm{II}}\left(\mathrm{NO}_{3}\right)_{2}$ sample remains stable in the SSZ-13 framework resulting in maintaining its high catalytic activity. Our work can help to understand the effect of anions originating from copper precursors on the structure and catalytic property and rational design of a $\mathrm{Cu}^{\mathrm{II}}-\mathrm{SSZ}-13$ catalyst for $\mathrm{NO}$ selective catalytic reduction with $\mathrm{NH}_{3}$ in diesel vehicle exhausts.

Supplementary Materials: The following are available online at http://www.mdpi.com/2073-4344/9/9/781/s1, Figure S1: XRD patterns of $\mathrm{Cu}^{\mathrm{II}}-\mathrm{SSZ}-13$ catalysts before (a) and after (b) hydrothermal aging treatment. Figure S2: Gaseous hourly space velocity (GHSV) of fresh $\mathrm{Cu}^{\mathrm{II}}-\mathrm{SSZ}-13$ catalyst synthesized by $\mathrm{Cu}^{\mathrm{II}}\left(\mathrm{NO}_{3}\right)_{2}$ as copper precursors.

Author Contributions: The experimental work was conceived and designed by M.W. and J.W.; M.W. and Z.P. performed the experiments; M.W. and M.L. analyzed the data and M.W. drafted the paper. The manuscript was amended through the comments of C.Z., W.B., L.C., L.H., Y.H., Z.H. and. All authors have given approval for the final version of the manuscript.

Funding: The authors gratefully thank the Project funded by China Postdoctoral Science Foundation (2019M651077).

Conflicts of Interest: The authors declare no conflict of interest.

\section{References}

1. Liu, F.; Yu, Y.; He, H. Environmentally-benign catalysts for the selective catalytic reduction of $\mathrm{NO}_{\mathrm{x}}$ from diesel engines: Structure-activity relationship and reaction mechanism aspects. Chem. Commun. 2014, 50, 8445-8463. [CrossRef] [PubMed]

2. Han, S.; Ye, Q.; Cheng, S.; Kang, T.; Dai, H. Effect of the hydrothermal aging temperature and $\mathrm{Cu} / \mathrm{Al}$ ratio on the hydrothermal stability of CuSSZ-13 catalysts for $\mathrm{NH}_{3}$-SCR. Catal. Sci. Technol. 2017, 7, 703-717. [CrossRef]

3. Xin, Y.; Li, Q.; Zhang, Z. Zeolitic materials for DeNO $\mathrm{N}_{x}$ selective catalytic reduction. ChemCatChem 2018, 10, 29-41. [CrossRef]

4. Wang, J.; Peng, Z;; Chen, Y.; Bao, W.; Chang, L.; Feng, G. In-situ hydrothermal synthesis of Cu-SSZ-13/cordierite for the catalytic removal of $\mathrm{NO}_{x}$ from diesel vehicles by $\mathrm{NH}_{3}$. Chem. Eng. J. 2015, 263, 9-19. [CrossRef]

5. Kwon, D.W.; Nam, K.B.; Hong, S.C. The role of ceria on the activity and $\mathrm{SO}_{2}$ resistance of catalysts for the selective catalytic reduction of $\mathrm{NO}_{x}$ by NH $\mathrm{N}_{3}$. Appl. Catal. B 2015, 166, 37-44. [CrossRef]

6. He, Y.; Ford, M.E.; Zhu, M.; Liu, Q.; Tumuluri, U.; Wu, Z.; Wachs, I.E. Influence of catalyst synthesis method on selective catalytic reduction (SCR) of no by $\mathrm{NH}_{3}$ with $\mathrm{V}_{2} \mathrm{O}_{5}-\mathrm{WO}_{3} / \mathrm{TiO}_{2}$ catalysts. Appl. Catal. B 2016, 193, 141-150. [CrossRef]

7. Joshi, S.Y.; Kumar, A.; Luo, J.; Kamasamudram, K.; Currier, N.W.; Yezerets, A. New insights into the mechanism of $\mathrm{NH}_{3}$-SCR over $\mathrm{Cu}$ - and Fe-zeolite catalyst: Apparent negative activation energy at high temperature and catalyst unit design consequences. Appl. Catal. B 2018, 226, 565-574. [CrossRef]

8. Xie, K.; Woo, J.; Bernin, D.; Kumar, A.; Kamasamudram, K.; Olsson, L. Insights into hydrothermal aging of phosphorus-poisoned Cu-SSZ-13 for $\mathrm{NH}_{3}$-SCR. Appl. Catal. B 2019, 241, 205-216. [CrossRef]

9. Cheng, J.; Han, S.; Ye, Q.; Cheng, S.; Kang, T.; Dai, H. Selective catalytic reduction of $\mathrm{NO}$ with $\mathrm{NH}_{3}$ over the $\mathrm{Cu} / \mathrm{SAPO}-34$ catalysts derived from different $\mathrm{Cu}$ precursors. Microporous Mesoporous Mater. 2019, 278, 423-434. [CrossRef]

10. Kwak, J.H.; Tran, D.; Burton, S.D.; Szanyi, J.; Lee, J.H.; Peden, C.H.F. Effects of hydrothermal aging on $\mathrm{NH}_{3}$-SCR reaction over Cu/zeolites. J. Catal. 2012, 287, 203-209. [CrossRef]

11. Han, L.; Zhao, X.; Yu, H.; Hu, Y.; Li, D.; Sun, D.; Liu, M.; Chang, L.; Bao, W.; Wang, J. Preparation of SSZ-13 zeolites and their $\mathrm{NH}_{3}$-selective catalytic reduction activity. Microporous Mesoporous Mater. 2018, 261, 126-136. [CrossRef]

12. Shishkin, A.; Kannisto, H.; Carlsson, P.-A.; Härelind, H.; Skoglundh, M. Synthesis and functionalization of SSZ-13 as an $\mathrm{NH}_{3}$-SCR catalyst. Catal. Sci. Technol. 2014, 4, 3917-3926. [CrossRef] 
13. Ren, L.; Zhu, L.; Yang, C.; Chen, Y.; Sun, Q.; Zhang, H.; Li, C.; Nawaz, F.; Meng, X.; Xiao, F.S. Designed copper-amine complex as an efficient template for one-pot synthesis of Cu-SSZ-13 zeolite with excellent activity for selective catalytic reduction of $\mathrm{NO}_{x}$ by $\mathrm{NH}_{3}$. Chem. Commun. 2011, 47, 9789-9791. [CrossRef] [PubMed]

14. Zhang, T.; Qiu, F.; Chang, H.; Li, X.; Li, J. Identification of active sites and reaction mechanism on low-temperature SCR activity over Cu-SSZ-13 catalysts prepared by different methods. Catal. Sci. Technol. 2016, 6, 6294-6304. [CrossRef]

15. Ma, Y.; Cheng, S.; Wu, X.; Shi, Y.; Cao, L.; Liu, L.; Ran, R.; Si, Z.; Liu, J.; Weng, D. Low-temperature solid-state ion-exchange method for preparing Cu-SSZ-13 selective catalytic reduction catalyst. ACS Catal. 2019, 9, 6962-6973. [CrossRef]

16. Paolucci, C.; Khurana, I.; Parekh, A.A.; Li, S.; Shih, A.J.; Li, H.; di Iorio, J.R.; Albarracin-Caballero, J.D.; Yezerets, A.; Miller, J.T.; et al. Dynamic multinuclear sites formed by mobilized copper ions in $\mathrm{NO}_{\mathrm{x}}$ selective catalytic reduction. Science 2017, 357, 898-903. [CrossRef]

17. Borfecchia, E.; Beato, P.; Svelle, S.; Olsbye, U.; Lamberti, C.; Bordiga, S. Cu-cha-A model system for applied selective redox catalysis. Chem. Soc. Rev. 2018, 47, 8097-8133. [CrossRef] [PubMed]

18. Marberger, A.; Petrov, A.W.; Steiger, P.; Elsener, M.; Kröcher, O.; Nachtegaal, M.; Ferri, D. Time-resolved copper speciation during selective catalytic reduction of no on Cu-SSZ-13. Nat. Catal. 2018, 1, $221-227$. [CrossRef]

19. Xu, R.; Pang, W.; Yu, J.; Huo, Q.; Chen, J. Molecular Sieves and Porous Materials Chemietry; Science Press: Beijing, China, 2004.

20. Kumar, R.; Mukherjee, P.; Pandey, R.K.; Rajmohanan, P.; Bhaumik, A. Role of oxyanions as promoter for enhancing nucleation and crystallization in the synthesis of MFI-type microporous materials. Microporous Mesoporous Mater. 1998, 22, 23-31. [CrossRef]

21. López-León, T.; Santander-Ortega, M.J.; Ortega-Vinuesa, J.L.; Bastos-González, D. Hofmeister Effects in Colloidal Systems: Influence of the Surface Nature. J. Phys. Chem. C 2008, 112, 16060-16069. [CrossRef]

22. Toktarev, A.V.; Echevskii, G.V. Hofmeister anion effect on the formation of zeolite beta. Stud. Surf. Sci. Catal. 2008, 174, 167-172.

23. Leontidis, E. Hofmeister anion effects on surfactant self-assembly and the formation of mesoporous solids. Curr. Opin. Colloid Interface Sci. 2002, 7, 81-91. [CrossRef]

24. Yang, Z. Hofmeister effects: An explanation for the impact of ionic liquids on biocatalysis. J. Biotechnol. 2009, 144, 12-22. [CrossRef] [PubMed]

25. Gao, F.; Walter, E.D.; Kollar, M.; Wang, Y.; Szanyi, J.; Peden, C.H.F. Understanding ammonia selective catalytic reduction kinetics over $\mathrm{Cu} / \mathrm{SSZ}-13$ from motion of the $\mathrm{Cu}$ ions. J. Catal. 2014, 319, 1-14. [CrossRef]

26. Ma, L.; Cheng, Y.; Cavataio, G.; McCabe, R.W.; Fu, L.; Li, J. Characterization of commercial Cu-SSZ-13 and $\mathrm{Cu}-\mathrm{SAPO}-34$ catalysts with hydrothermal treatment forNH $\mathrm{H}_{3}-\mathrm{SCR}$ of $\mathrm{NO}_{\mathrm{x}}$ in diesel exhaust. Chem. Eng. J. 2013, 225, 323-330. [CrossRef]

27. Kwak, J.H.; Tonkyn, R.G.; Kim, D.H.; Szanyi, J.; Peden, C.H.F. Excellent activity and selectivity of Cu-SSZ-13 in the selective catalytic reduction of $\mathrm{NO}_{x}$ with $\mathrm{NH}_{3}$. J. Catal. 2010, 275, 187-190. [CrossRef]

28. Zhu, H.; Kwak, J.H.; Peden, C.H.F.; Szanyi, J. In situ DRIFTS-MS studies on the oxidation of adsorbed $\mathrm{NH}_{3}$ by $\mathrm{NO}_{x}$ over a Cu-SSZ-13 zeolite. Catal. Today 2013, 205, 16-23. [CrossRef]

29. Wang, J.; Peng, Z.; Qiao, H.; Yu, H.; Hu, Y.; Chang, L.; Bao, W. Cerium-Stabilized Cu-SSZ-13 Catalyst for the Catalytic Removal of $\mathrm{NO}_{x}$ by $\mathrm{NH}_{3}$. Ind. Eng. Chem. Res. 2016, 55, 1174-1182. [CrossRef]

30. Fan, C.; Chen, Z.; Pang, L.; Ming, S.; Dong, C.; Brou Albert, K.; Liu, P.; Wang, J.; Zhu, D.; Chen, H.; et al. Steam and alkali resistant $\mathrm{Cu}$-SSZ-13 catalyst for the selective catalytic reduction of $\mathrm{NO}_{\mathrm{x}}$ in diesel exhaust. Chem. Eng. J. 2018, 334, 344-354. [CrossRef]

31. Xie, L.; Liu, F.; Ren, L.; Shi, X.; Xiao, F.S.; He, H. Excellent performance of one-pot synthesized Cu-SSZ-13 catalyst for the selective catalytic reduction of $\mathrm{NO}_{x}$ with $\mathrm{NH}_{3}$. Environ. Sci. Technol. 2014, 48, 566-572. [CrossRef]

32. Zhang, T.; Qiu, F.; Li, J. Design and synthesis of core-shell structured meso-Cu-SSZ-13@mesoporous aluminosilicate catalyst for SCR of $\mathrm{NO}_{x}$ with $\mathrm{NH}_{3}$ : Enhancement of activity, hydrothermal stability and propene poisoning resistance. Appl. Catal. B 2016, 195, 48-58. [CrossRef] 
33. Xu, M.; Wang, J.; Yu, T.; Wang, J.; Shen, M. New insight into Cu/SAPO-34 preparation procedure: Impact of $\mathrm{NH}_{4}$-SAPO-34 on the structure and $\mathrm{Cu}$ distribution in Cu-SAPO-34 $\mathrm{NH}_{3}$-SCR catalysts. Appl. Catal. B 2018, 220, 161-170. [CrossRef]

34. Chen, Z.; Fan, C.; Pang, L.; Ming, S.; Liu, P.; Li, T. The influence of phosphorus on the catalytic properties, durability, sulfur resistance and kinetics of Cu-SSZ-13 for $\mathrm{NO}_{x}$ reduction by $\mathrm{NH}_{3}$-SCR. Appl. Catal. B 2018, 237, 116-127. [CrossRef]

35. Fickel, D.W.; Lobo, R.F. Coordination in Cu-SSZ-13 and Cu-SSZ-16 Investigated by Variable-Temperature XRD. J. Phys. Chem. C 2009, 114, 1633-1640. [CrossRef]

36. Deka, U.; Juhin, A.; Eilertsen, E.A.; Emerich, H.; Green, M.A.; Korhonen, S.T.; Weckhuysen, B.M.; Beale, A.M. Confirmation of Isolated $\mathrm{Cu}^{2+}$ Ions in SSZ-13 Zeolite as Active Sites in $\mathrm{NH}_{3}$-Selective Catalytic Reduction. J. Phys. Chem. C 2012, 116, 4809-4818. [CrossRef]

37. Chen, J.; Zhao, R.; Zhou, R. A new insight into active $\mathrm{Cu}^{2+}$ Species Properties in One-Pot Synthesized Cu-SSZ-13 Catalysts for $\mathrm{NO}_{x}$ Reduction by $\mathrm{NH}_{3}$. ChemCatChem 2018, 10, 5182-5189. [CrossRef]

38. Gao, F.; Washton, N.M.; Wang, Y.; Kollár, M.; Szanyi, J.; Peden, C.H.F. Effects of Si/Al ratio on Cu/SSZ-13 $\mathrm{NH}_{3}$-SCR catalysts: Implications for the active $\mathrm{Cu}$ species and the roles of Brønsted acidity. J. Catal. 2015, 331, 25-38. [CrossRef]

39. Gao, F.; Wang, Y.; Washton, N.M.; Kollár, M.; Szanyi, J.; Peden, C.H.F. Alkali and Alkaline Earth Cocations on the Activity and Hydrothermal Stability of Cu/SSZ-13 NH 3 -SCR Catalysts. ACS Catal. 2015, 5, 6780-6791. [CrossRef]

40. Lezcano-Gonzalez, I.; Deka, U.; van der Bij, H.E.; Paalanen, P.; Arstad, B.; Weckhuysen, B.M.; Beale, A.M. Chemical deactivation of $\mathrm{Cu}-\mathrm{SSZ}-13$ ammonia selective catalytic reduction $\left(\mathrm{NH}_{3}-\mathrm{SCR}\right)$ systems. Appl. Catal. B 2014, 154, 339-349. [CrossRef]

41. Wang, J.; Liu, Z.; Feng, G.; Chang, L.; Bao, W. In situ synthesis of CuSAPO-34/cordierite and its selective catalytic reduction of nitrogen oxides in vehicle exhaust: The effect of HF. Fuel 2013, 109, 101-109. [CrossRef]

42. Chen, B.; Xu, R.; Zhang, R.; Liu, N. Economical Way to Synthesize SSZ-13 with abundant ion-exchanged Cu ${ }^{+}$ for an extraordinary performance in selective catalytic reduction (SCR) of $\mathrm{NO}_{\mathrm{x}}$ by ammonia. Environ. Sci. Technol. 2014, 48, 13909-13916. [CrossRef] [PubMed]

43. Song, J.; Wang, Y.; Walter, E.D.; Washton, N.M.; Mei, D.; Kovarik, L.; Engelhard, M.H.; Prodinger, S.; Wang, Y.; Peden, C.H.F.; et al. Toward rational design of $\mathrm{Cu} / \mathrm{SSZ}-13$ selective catalytic reduction catalysts: Implications from atomic-level understanding of hydrothermal stability. ACS Catal. 2017, 7, 8214-8227. [CrossRef]

44. Wu, L.; Degirmenci, V.; Magusin, P.C.M.M.; Lousberg, N.J.H.G.M.; Hensen, E.J.M. Mesoporous SSZ-13 zeolite prepared by a dual-template method with improved performance in the methanol-to-olefins reaction. J. Catal. 2013, 298, 27-40. [CrossRef]

45. Prodinger, S.; Derewinski, M.A.; Wang, Y.; Washton, N.M.; Walter, E.D.; Szanyi, J.; Gao, F.; Wang, Y.; Peden, C.H.F. Sub-micron Cu/SSZ-13: Synthesis and application as selective catalytic reduction (SCR) catalysts. Appl. Catal. B 2017, 201, 461-469. [CrossRef]

46. Martins, G.A.V.; Berlier, G.; Coluccia, S.; Pastore, H.O.; Superti, G.B.; Gatti, G.; Marchese, L. Revisiting the nature of the acidity in chabazite-related Silicoaluminophosphates: Combined FTIR and ${ }^{29}$ Si MAS NMR study. J. Phys. Chem. C 2007, 111, 330-339. [CrossRef]

47. Xu, L.; Du, A.; Wei, Y.; Wang, Y.; Yu, Z.; He, Y.; Zhang, X.; Liu, Z. Synthesis of SAPO-34 with only Si(4Al) species: Effect of Si contents on Si incorporation mechanism and Si coordination environment of SAPO-34. Microporous and Mesoporous Mater. 2008, 115, 332-337. [CrossRef]

48. Barthomeuf, D. Topological model for the compared acidity of SAPOs and SiAl zeolites. Zeolites 1994, 14, 394-401. [CrossRef] 
49. Ren, L.; Zhang, Y.; Zeng, S.; Zhu, L.; Sun, Q.; Zhang, H.; Yang, C.; Meng, X.; Yang, X.; Xiao, F.-S. Design and synthesis of a catalytically active Cu-SSZ-13 zeolite from a copper-amine complex template. Chin. J. Catal. 2012, 33, 92-105. [CrossRef]

50. Wang, J.; Peng, Z.; Qiao, H.; Han, L.; Bao, W.; Chang, L.; Feng, G.; Liu, W. Influence of aging on in situ hydrothermally synthesized Cu-SSZ-13 catalyst for $\mathrm{NH}_{3}-\mathrm{SCR}$ reaction. RSC Adv. 2014, 4, 42403-42411. [CrossRef]

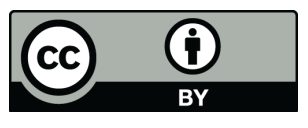

(C) 2019 by the authors. Licensee MDPI, Basel, Switzerland. This article is an open access article distributed under the terms and conditions of the Creative Commons Attribution (CC BY) license (http://creativecommons.org/licenses/by/4.0/). 